\title{
Teaching NeuroImages: Sleep-onset REM period during routine $\mathrm{EEG}$
}

Karl A. Kasischke, MD, Amanda Pennington, MD, PhD, and Selim R. Benbadis, MD

Neurology ${ }^{\circledR}$ 2019;93:e1123-e1124. doi:10.1212/WNL.0000000000008108

Figure Two consecutive EEG pages in bilateral longitudinal (double banana) montage

A

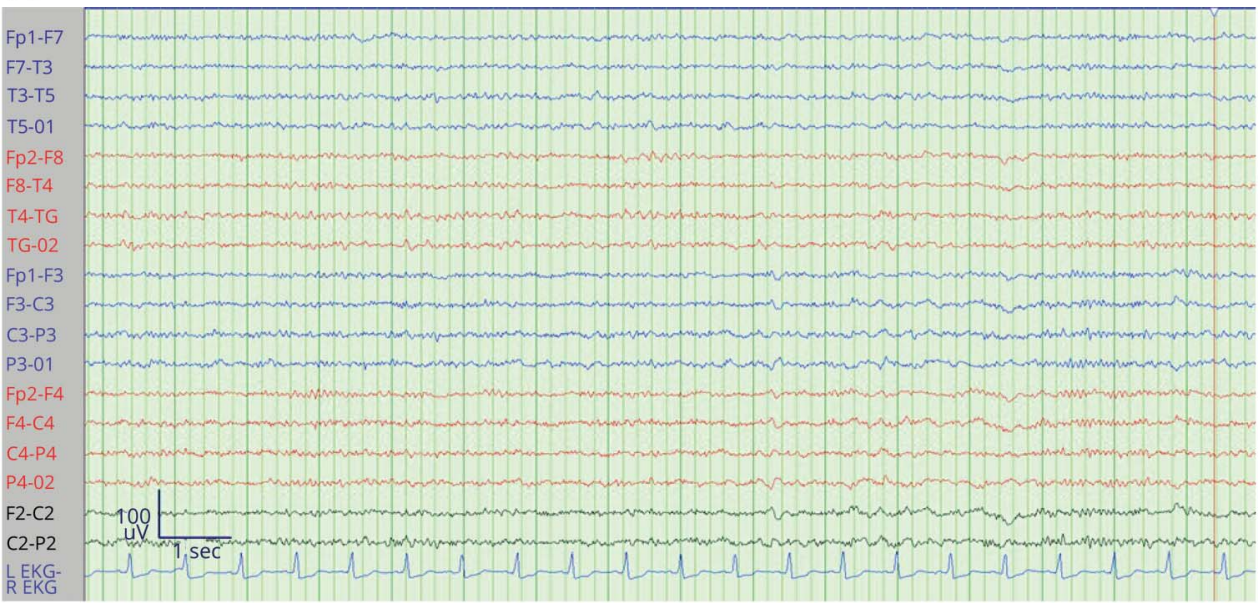

B

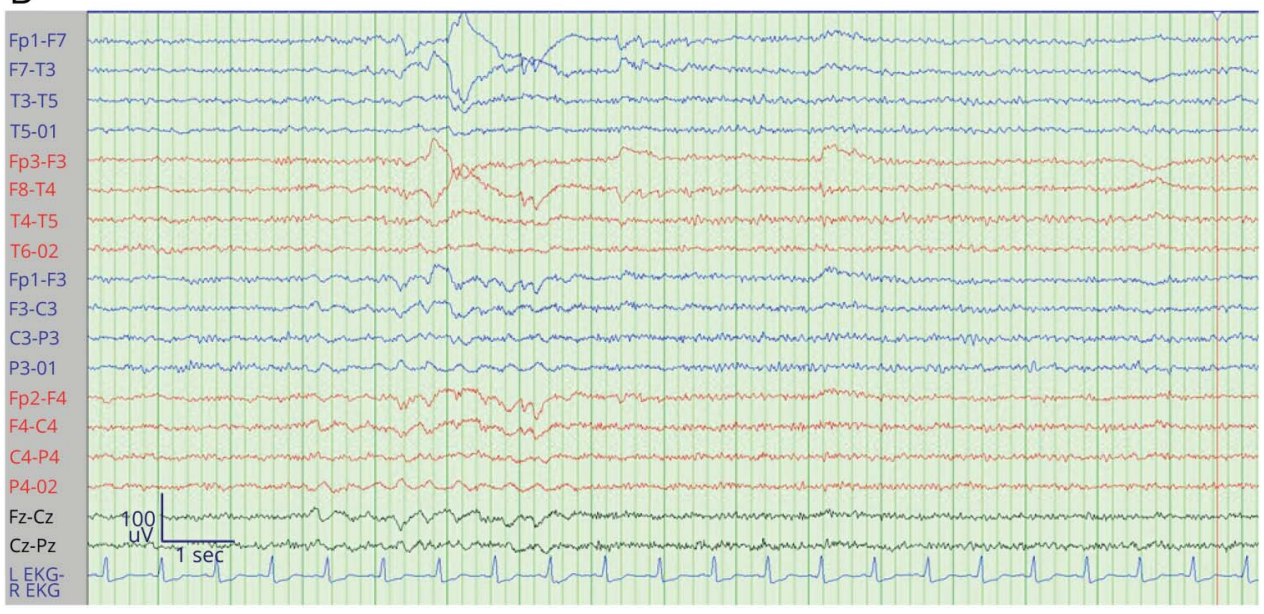

(A) EEG sample with sleep spindles in normal stage N2 sleep. (B) On the contiguous second page, there is a burst of high-amplitude lateral eye movements with concurrent sawtooth waves, indicative of REM. Also note muscle quiescence. This sleep-onset REM period could be misinterpreted as sharp waves.

A 76-year-old incarcerated man presented with word-finding difficulties and underwent a routine EEG. Shortly after reaching stage N2 sleep, EEG showed brisk lateral eye movements with concurrent sawtooth waves (figure), indicating sleep-onset REM period (SOREMP). Normal REM sleep is reached $90-120$ minutes after sleep onset. SOREMP is an abnormal EEG

\author{
Correspondence \\ Dr. Kasischke \\ kkasischke@health.usf.edu
}

\section{MORE ONLINE}

$\rightarrow$ Teaching slides

links.lww.com/WNL/

A950 
finding thought to be suggestive of narcolepsy. However, it may also be present in $3.9 \%$ of the general population ${ }^{1}$ and is normal in infants. It is also associated with severe sleep deprivation, obstructive sleep apnea, and alcohol or medication (selective serotonin reuptake inhibitors, serotonin and norepinephrine reuptake inhibitors, tricyclic antidepressants, monoamine oxidase inhibitors) withdrawal. In the inpatient setting, it is usually caused by sleep deprivation. ${ }^{2}$

\section{Study funding}

No targeted funding reported.

\section{Disclosure}

The authors report no disclosures relevant to the manuscript. Go to Neurology.org/N for full disclosures.
Appendix Authors

\begin{tabular}{llll}
\hline Name & Location & Role & Contribution \\
\hline $\begin{array}{l}\text { Karl A. } \\
\text { Kasischke, MD }\end{array}$ & $\begin{array}{l}\text { University of } \\
\text { South Florida, } \\
\text { Tampa }\end{array}$ & Author & $\begin{array}{l}\text { Analyzed data, drafted } \\
\text { and revised the } \\
\text { manuscript }\end{array}$ \\
\hline $\begin{array}{l}\text { Amanda } \\
\text { Pennington, } \\
\text { MD, PhD }\end{array}$ & $\begin{array}{l}\text { University of } \\
\text { South Florida, } \\
\text { Tampa }\end{array}$ & Author & $\begin{array}{l}\text { Analyzed and presented } \\
\text { data }\end{array}$ \\
\hline $\begin{array}{l}\text { Selim R. } \\
\text { Benbadis, MD }\end{array}$ & $\begin{array}{l}\text { University of } \\
\text { South Florida, }\end{array}$ & Author & $\begin{array}{l}\text { Designed study and } \\
\text { revised the manuscript }\end{array}$ \\
& Tampa & \\
\hline
\end{tabular}

\section{References}

1. Sing M, Drake CL, Roth T. The prevalence of multiple sleep-onset REM periods in a population-based sample. Sleep 2006;29:890-895.

2. Gangadhara S, Pizarro-Otero J, Bozorg A, Benbadis S. The significance of REM sleep on routine EEG. Neurodiagn J 2016;56:37-40. 


\section{Neurology}

\section{Teaching NeuroImages: Sleep-onset REM period during routine EEG}

Karl A. Kasischke, Amanda Pennington and Selim R. Benbadis

Neurology 2019;93; e1123-e1124

DOI 10.1212/WNL.0000000000008108

This information is current as of September 9, 2019

Updated Information \& Services

References

Subspecialty Collections

Permissions \& Licensing

Reprints including high resolution figures, can be found at: http://n.neurology.org/content/93/11/e1123.full

This article cites 2 articles, 0 of which you can access for free at: http://n.neurology.org/content/93/11/e1123.full\#ref-list-1

This article, along with others on similar topics, appears in the following collection(s):

All clinical neurophysiology

http://n.neurology.org/cgi/collection/all_clinical_neurophysiology EEG

http://n.neurology.org/cgi/collection/eeg

Narcolepsy

http://n.neurology.org/cgi/collection/narcolepsy

Information about reproducing this article in parts (figures,tables) or in its entirety can be found online at:

http://www.neurology.org/about/about_the_journal\#permissions

Information about ordering reprints can be found online:

http://n.neurology.org/subscribers/advertise

Neurology ${ }^{\circledR}$ is the official journal of the American Academy of Neurology. Published continuously since 1951, it is now a weekly with 48 issues per year. Copyright @ 2019 American Academy of Neurology. All rights reserved. Print ISSN: 0028-3878. Online ISSN: 1526-632X.

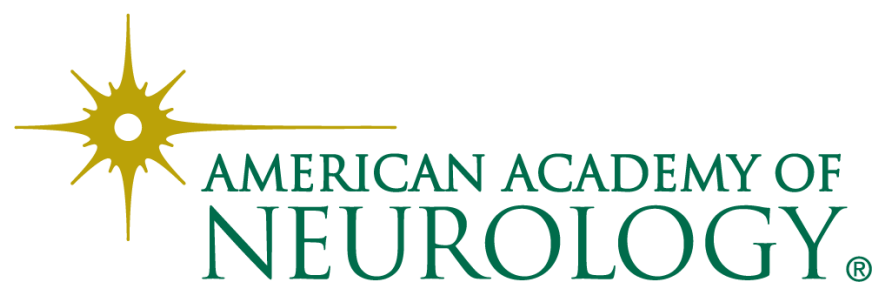

